\title{
PENGARUH STRATEGI PEMASARAN TERHADAP PENINGKATAN JUMLAH NASABAH DI PT. BPR ASWAJA PONOROGO
}

\author{
Yuniska Prasetyanti \\ Mahasiswa Prodi Pendidikan Ekonomi IKIP PGRI Madiun
}

\begin{abstract}
The purpose of the research is (1) to know marketing strategy in PT. BPR Aswaja Ponorogo, (2) to know the improvement of the amount of client in PT. BPR Aswaja Ponorogo, (3) to know there is or do not it him influence of marketing strategy to make-up of the amount of client in PT. BPR Aswaja Ponorogo. The samples in this study using a sample of intended. The sample in this study is over 10 years old. Data collection using documentation and interviews to collect data marketing strategy and the number of customers in the PT. BPR Aswaja. Observation method is used to retrieve data marketing strategy. The data analysis technique used in this study is a simple linear regression analysis and the influence of different test. Result of research indicate that marketing strategy have influence at the same time relation which are positive to improvement of client amount in PT. BPR Aswaja Ponorogo. Matter this means value of thitung $>\operatorname{ttabel}(3,524>1,859)$ hence refusing Ho with the meaning that there is influence between marketing strategy to make-up of the amount of client in PT. BPR Aswaja Ponorogo. Pursuant to research above, seen there is influence of marketing strategy to improvement of the amount of client in PT. BPR Aswaja Ponorogo.
\end{abstract}

Keywords: Marketing strategy, amount of client.

\begin{abstract}
Abstrak: Penelitian ini bertujuan (1) Untuk mengetahui Strategi pemasaran pada PT. BPR Aswaja Ponorogo, (2) Untuk mengetahui peningkatan jumlah nasabah pada PT. BPR Aswaja Ponorogo, dan (3) Untuk mengetahui ada atau tidaknya pengaruh antara strategi pemasaran terhadap peningkatan jumlah nasabah pada PT. BPR Aswaja Ponorogo. Sampel dalam penelitian ini yaitu selama 10 tahun. Pengumpulan data menggunakan metode dokumentasi dan wawancara untuk mengambil data strategi pemasaran dan jumlah nasabah di PT. BPR Aswaja Ponorogo. Metode observasi digunakan untuk mengambil data strategi pemasaran. Teknik analisis data yang digunakan dalam penelitian ini adalah analisis regresi linier sederhana dan uji beda pengaruh. Hasil penelitian menunjukkan bahwa strategi pemasaran mempunyai pengaruh sekaligus hubungan yang positif terhadap peningkatan jumlah nasabah pada PT. BPR Aswaja Ponorogo. Hal ini berarti nilai thitung $>$ ttabel $(3,524>1,859)$ maka tolak Ho yang artinya bahwa ada pengaruh antara strategi pemasaran terhadap peningkatan jumlah nasabah pada PT. BPR Aswaja Ponorogo. Berdasarkan penelitian di atas, terlihat bahwa ada pengaruh strategi pemasaran terhadap peningkatan jumlah nasabah PT. Aswaja Ponorogo.
\end{abstract}

Kata kunci : Strategi Pemasaran, Jumlah Nasabah

\section{PENDAHULUAN}

Dunia perbankan berkembang dengan pesat sejak dikeluarkannya kebijakan peme- rintah bidang perbankan yang dikenal dengan paket Oktober 1988, yang berisi tentang diperkenankannya pendirian bank swasta 
nasional, bank pengkreditan rakyat dan memberi kemudahan pembukaan kantor baru. Telah dicatat oleh bank Indonesia pada akhir September 1988 ada 111 bank umum yang beroperasi dengan 1.728 kantor pelayanan dan 7.706 kantor untuk bank perkreditan rakyat. Jumlah tersebut terus bertambah sehingga pada tahun 1995 terdapat 240 bank umum dengan 5.288 kantor pelayanan sedangkan bank pengkreditan rakyat berkembang menjadi 8.993 buah. Sehingga pada akhir tahun 1995 jumlah bank di Indonesia sebanyak 9.238 dengan kantor pelayanan 14.286 buah.

Bank Perkreditan Rakyat sebagai salah satu bank yang melaksanakan kegiatan usahanya bersadasarkan prinsip syariah yang dalam kegiatannya tidak memberikan jasa dalam lalu lintas pembayaran. Jenis produk yang ditawarkan oleh Bank Perkreditan Rakyat relatif lebih sempit apabila dibandingkan dengan bank umum, bahkan ada beberapa jenis jasa bank yang tidak boleh diselenggarakan oleh. Bank Perkreditan Rakyat, seperti pembukaan rekening giro dan ikut kliring. Elisabeth R. Simamora (dalam http://id.pdfsb.com/readonline, 2007:1).

Menurut Kasmir (2007: 2) Bank merupakan lembaga keuangan yang kegiatan usahanya menghimpun dana dari masyarakat dalam bentuk simpanan, menyalurkan dana kemasyarakat dan memberikan jasa-jasa bank lainnya seperti pengiriman uang (transfer), penagihan surat-surat berharga yang berasal dari luar kota dan luar negeri (inkaso). Dengan semaraknya persaingan usaha perbankkan saat ini, perusahaan perbankkan harus menerapkan strategi dengan baik agar para nasabah tertarik untuk memutuskan menabung.

Bank sebagai lembaga keuangan yang menghasilkan jasa keuangan juga membutuhkan strategi pemasaran untuk memasarkan produknya. Disini peran pemasaran sangat diperlukan untuk memperkenalkan keunggulan dari jasa perbankkan seperti tabungan, giro, rekening koran dan lain-lain dalam meningkatkan calon nasabah.

Guna menghadapi persaingan yang begitu ketat perlu dilakukan strategi-strategi pemasaran yang tepat untuk meningkatkan jumlah nasabah. Pemasaran harus di kelola secara profesional sehingga kebutuhan dan keinginan pelanggan akan segera terpenuhi dan terpuaskan. Oleh karena itu, bagi dunia perbankkan yang merupakan badan udaha yang berorientasi profit, kegiatan pemasaran sudah merupakan suatu kebutuhan utama dan sudah merupakan suatu keharusan untuk dijalankan. Tanpa kegiatan pemasaran jangan diharapkan kebutuhan dan keinginan pelanggannya akan terpenuhi. Karena itu, bagi usaha perbankkan perlu mengemas kegiatan pemasarannya secara terpadu dan terus menerus melakukan riset pasar. Sehingga bank dapat seoptimal mungkin dapat menarik perhatian dan simpatik masyarakat, baik dalam menghimpun dana maupun meningkatkan jumlah nasabahnya.

Salah satu cara untuk menghimpun dana adalah dengan menawarkan produk bank, produk yang ditawarkan oleh bank semakin beragam, dengan memberikan berbagai kemudahan-kemudahan dan tingkat suku bunga yang kompetitif. Hal ini jika dilihat dari sudut pandang nasabah, berarti keuntungan buat nasabah, karena semakin banyak pilihan produk yang ditawarkan. seperti produk simpanan (giro, tabungan, deposito), pinjaman (kredit), atau jasa-jasa bank lainnya seperti transfer, kliring, inkaso, safe deposit box, kartu kredit, letter of credit, bank garansi, traveller cheque, bank draf, dan jasa-jasa bank lainnya.

Sofjan Assauri, (2010: 168) Strategi pemasaran merupakan suatu rencana yang menyeluruh, terpadu dan menyatu di bidang pemasaran, yang memberikan panduan tentang kegiatan yang akan dijalankan untuk dapat tercapainya tujuan pemasaran suatu perusahaan. Dengan demikian, strategi pemasaran harus dapat memberi gambaran yang jelas dan terarah tentang apa yang akan dilakukan perusahaan dalam menggunakan 
setiap kesempatan atau peluang beberapa pasar sasaran. Dalam hal ini dibutuhkan dunia bagian yang sangat penting dan berkaitan, untuk mencapai keberhasilan kegiatan pemasaran yang dilakukan oleh suatu perusahaan, yaitu sasaran pasar yang dituju (target market), dan acuan pemasaran yang dijalankan (marketing mix) untuk sasaran pasar.Strategi pemasaran terdiri dari unsur pemasaran yang terpadu yaitu strategi produk, strategi harga, strategi penyaluran atau distribusi dan strategi promosi. Keempat strategi tersebut saling mempengaruhi (independent), sehingga semuanya penting sebagai satu kesatuan strategi, yaitu strategi acuan atau bauran.

Nasabah adalah pihak yang menggunakan jasa Bank dan memiliki rekening pada Bank tersebut. Gubernur Bank Indonesia (dalam http://hukum.unsrat.ac.id, 2009: 4).

Nasabah adalah orang atau badan yang mempunyai rekening simpanan atau pinjaman pada bank. Djaslim Saladin (dalam http://mirave21.wordpress.com, 2012:2).

Dari definisi di atas dapat disimpulkan bahwa nasabah adalah orang yang sudah menjadi pelanggan bank dan sudah mempunyai rekening dan simpanan pinjaman.

Untuk mencapai tujuan nasabah tersebut dapat dilakukan dengan berbagai cara dan salah satunya adalah memberikan kepuasan nasabah atau pelanggan. Kepuasan nasabah menjadi sangat bernilai bagi bank atau perusahaan, sehingga tidak heran selalu ada slogan bahwa pelanggan adalah raja, yang perlu dilayani dengan sebaikbaiknya.

Menurut Kasmir (2010:161) Dalam praktiknya apabila nasabah puas atas pelayanan yang yang diberikan bank, maka ada dua keuntungan yang diterima bank, yaitu:

1) Nasabah yang lama akan tetap dapat dipertahankan atau dengan kata lain nasabah loyal kepada bank.

2) Kepuasan nasabah lama akan menular kepada nasabah baru, dengan berbagai cara, sehingga mampu meningkatkan jumlah nasabah.

Faktor-faktor yang mempengaruhi nasabah:

a. Produk yang ditawarkan cukup beragam

b. Pelayanan yang baik dan Kecepatan dalam melayani nasabah

c. Strategi pemasaran yang tepat

d. Biaya bunga ringan

e. Besarnya hadiah yang ditawarkan

f. Kelebihan produk yang ditawarkan

Menurut Basu Swasta (2008: 67) "Strategi adalah suatu rencana yang diutamakan untuk mencapai suatu tujuan tersebut". Beberapa perusahaan mungkin mempunyai tujuan yang sama, tetapi strategi yang dipakai untuk mencapai tujuan tersebut dapat berbeda. Jadi strategi ini dibuat berdasarkan sutu tujuan.

Menurut Thamrin Abdullah dan Francis Tantri (2012: 2) "secara lebih formal, pemasaran adalah suatu sistem total dari kegiatan bisnis yang dirancang untuk merencanakan, menetukan harga, mempromosikan dan menditribusikan barang-barang yang dapat memuaskan keinginan dan jasa baik kepada para konsumen saat ini maupun konsumen potensial".

Menurut Sofjan Assauri (2010: 198) "strategi pemasaran adalah himpunan atas yang secara tepat, konsisten, dan layak dilaksanakan oleh perusahaan guna mencapai sasaran pasar yang dituju (target market) dalam jangka panjang, dalam dituasi persainga tertentu".

Oleh karena itu, penentuan strategi pemasaran harus didasarkan atas analisis lingkungan dan internal perusahaan melalui analisis keunggulan dan kelemahan perusahaan, serta analisi kesempatan dan ancaman yang dihadapi perusahaan dari lingkungannya.

Dari definisi di atas dapat disimpulkan bahwa strategi pemasaran adalah suatu perencanaan yang ditempuh perusahaan dalam menentukan harga, mempromosikan suatu barang dan jasa kepada calon nasabah. 
Rambat Lupiyoadi (2001: 34) "Segmentasi pasar adalah membagi pasar menjadi kelompok pembeli yang dibedakan menurut kebutuhan, karakteristik, atau tingkah laku, yang mungkin membutuhkan produk yang berbeda".

Basu Swasta dan Irawan (2008: 89) "Segmentasi pasar adalah kegiatan membagibagi pasar yang bersifat heterogen dari suatu produk ke dalam satuan-satuan pasar (segmen pasar) yang bersifat homogen"

Sofjan Assauri, (2010:198) "Marketing mix merupakan kombinasi variabel atau kegiatan yang merupakan inti dari sistem pemasaran, variabel yang dapat dikendalikan oleh perusahaan untuk mempengaruhi reaksi para pembeli atau konsumen".

Buchari Alma, (2011: 205) "Marketing mix merupakan strategi mencampur kegiatankegiatan marketing, agar dicari konminasi maksimal sehingga mendatangkan hasil memuaskan".

Menurut Kotler (dalam Kasmir, 2010: 119) menyebutkan konsep baurau pemasaran (marketing mix) terdiri dari empat $\mathrm{P}(4 \mathrm{P})$, yaitu :

1) Produk (Product),

2) Harga (Price)

3) Lokasi (Place)

4) Promosi (Promotion)

Keempat strategi tersebut di atas mempengaruhi (independent), sehingga semuanya penting sebagai satu kesatuan strategi, yaitu Strategi Acuan atau Bauran. Sedangkan strategi marketing mix ini merupakan bagian dari strategi pemasaran (marketing strategy), dan berfungsi sebagai pedoman dalam menggunakan unsur-unsur atau variabel-variabel pemasaran yang dapat dikendalikan pimpinan perusahaan, untuk mencapai tujuan perusahaan, untuk mencapai tujuan perusahaan.

Kasmir (2010: 131) "Daur hidup produk yang artinya merupakan perjalanan hidup suatu produk mulai dari produk dijual di pasar sampai produk tersebut mati”.

Setiap perusahaan mempunyai tujuan untuk tetap hidup dan berkembang. Tujuan tersebut hanya dapat dicapai melalui usaha mempertahankan dan meningkatkan tingkat keuntungan atau laba perusahaan. Tujuan ini hanya dapat dicapai, apabila bagian pemasaran perusahaan melakukan strategi yang mantap untuk dapat menggunakan kesempatan atau peluang yang ada dalam pemasaran, sehingga posisi atau kedudukan perusahaan dapat dipertahankan dan sekaligus ditingkatkan. Strategi pemasaran sangatlah penting bagi pelaku usaha untuk keberhasilan usahanya, apalagi yang berhubungan dengan bidang pemasaran jasa.

Sofjan Assauri (2010:175) seperti diketahui, "Pemasaran adalah aktivitas atau kegiatan yang ditujukan untuk memenuhui kebutuhan dan keinginan konsumen melalui proses pertukaran". Oleh karena itu, strategi pemasaran yang berhasilan sangat ditentukan oleh tingkat kepuasan konsumen yang diperolehnya dari kegiatan pemasaran yang dilakukan perusahaan untuk produknya.Atas dasar ini maka dapat dikatakan bahwa tujuan dan sasaran pemasaran produk adalah untuk memberikan kepuasan kepada konsumen produk tersebut, di mana ditetapkan strategi pemasaran yang tepat.

Sofjan Assauri (2010:177) "Penetapan strategi sasaran pasar merupakan hasil perkembangan terakhir dari pendekatan atau pandangan pimpinan perusahaan dalam memasarkan produknya".

Menurut Kasmir (2010: 54) "Pemasaran bank adalah suatu proses untuk menciptakan dan mempertukarkan produk atau jasa bank yang ditunjukkan untuk memenuhi kebutuhan dan keinginan nasabah dengan cara memberikan kepuasan". Setiap perusahaan mempunyai tujuan untuk tetap hidup dan berkembang.Tujuan pemasaran bank adalah untuk memaksimumkan konsumsi, atau dengan kata lain, memudahkan dan merangsang konsumsi, sehingga dapat menarik nasabah untuk membeli produk yang ditawarkan bank secara berulang-ulang. Tujuan ini dapat tercapai, apabila bagian 
pemasaran perusahaan melakukan strategi pemasaran yang mantap untuk dapat menggunakan kesempatan atau peluang yang ada dalam pemasaran, sehingga posisi atau kedudukan perusahaan di pasar dapat dipertahankan dan sekaligus ditingkatkan.

Strategi pemasaran sangatlah penting bagi pelaku usaha untuk keberhasilan usahanya. Oleh karena itu, perusahaan harus berusaha mempengaruhi para konsumen, untuk menciptakan permintaan atas produk itu, kemudian dipelihara dan dikembangkan. Usaha tersebut dapat dilakukan melalui startegi promosi, yang merupakan salah satu dari acuan atau bauran pemasaran. Kegiatan promosi yang dilakukan sejalan dengan rencana pemasaran secara keseluruhan, serta direncanakan akan diarahkan dan dikendalikan dengan baik, diharapkan dapat berperan secara berarti dalam meningkatkan jumlah nasabah di PT. BPR. Selain itu kegiatan promosi ini juga akan diharapkan akan mempertahankan para nasabahnya. Dalam rangka menunjang keberhasilan kegiatan pemasaran yang dilakukan dan efektifitasnya rencana pemasaran yang disusun, maka perusahaan haruslah menetapkan dan menjalankan strategi pemasaran yang tepat.

Keberhasilan usaha penjualan dapat dilihat dari peningkatan jumlah nasabah yang didapat. Dengan kata lain apakah usaha itu dapat laba atau tidak, sangat tergantung pada keberhasilan penjualan dalam melakukan strategi pemasaran. Sehingga setiap pelaku usaha harus mempunyai strategistrategi pemasaran yang dapat mempertahankan kelangsungan hidup perusahaan dan persaingan yang semakin ketat.

\section{METODE PENELITIAN}

Tempat penelitian dilaksanakan di PT. BPR Aswaja dengan alamat jln. Bataro Katong No. 87 Ponorogo.Waktu yang diperlukan dalam penelitian ini yaitu selama 3 bulan, dari bulan Oktober sampai bulan Desember 2013. Penelitian ini termasuk dalam kelompok penelitian kuantitatif.
Menurut Sugiyono (2006:14) metode penelitian kuantitatif dapat diartikan sebagai metode penelitian yang berlandaskan pada filsafat positivisme, digunakan untuk meneliti pada populasi atau sampel tertentu, pengumpulan data menggunakan instrumen penelitian, analisis data bersifat kuantitatif atau statistik, dengan tujuan untuk menguji hipitesis yang telah ditetapkan. Adapun desain penelitian yang digunakan dalam penelitian ini adalah desain penelitian deskriptif yaitu penelitian bukan eksperimen karena tidak dimaksudkan untuk mengetahui akibat dari perlakuan. Dengan penelitian deskriptif peneliti hanya bermaksud menggambarkan atau menerangkan gejala (Suharsimi Arikunto, 2009: 250).

Dalam penelitian ini terdapat dua variabel yang digunakan yaitu variabel bebas $(\mathrm{X})$ adalah strategi pemasaran dan variabel terikat (Y) adalah peningkatan jumlah nasabah.

\section{Populasi dan Sampel Penelitian}

Adapun populasi dalam penelitian ini adalah semua nasabah PT. BPR Aswaja Ponorogo mulai berdirinya tahun 2002 sampai tahun 2012. Berdasarkan pada populasi tersebut maka sampel dalam penelitian ini adalah selama 10 tahun yaitu nasabah PT. BPR Aswaja Ponorogo dari tahun 2003 sampai 2012.

Teknik pengambilan sampel yang akan digunakan dalam penelitian ini adalah teknik sampel bertujuan. Menurut Gabriel Amin Silalahi (2003: 74) sampel bertujuan adalah penelitian menggunakan pertimbangan sendiri (dengan berbekal pengetahuan yang cukup tentang populasi) untuk memilih anggota-anggota sampel. Data yang diperoleh dari purposive sampling paling banyak akan memberikan arah kesimpulan, tetapi pada pada umumnya tidak dapat digunakan sebagai dasar pengujian statistik.

\section{Teknik Pengumpulan Data}

Adapun teknik yang digunakan peneliti untuk pengumpulan data ini adalah : 


\section{Dokumentasi}

Menurut Suharsimi Arikunto (2002: 135) Dokumentasi dari asal katanya dokumen yang artinya barang-barang tertulis. Di dalam melaksanakan metode dokumentasi, peneliti menyelididki benda-benda tertulis, seperti buku-buku, majalah, dokumen, peraturan-peraturan, notulen rapat, catatan harian, dan sebagainya. Dengan demikian, teknik pengumpulan data dengan dokumentasi ini yaitu memperoleh data dengan cara mencatat dokumen-dokumen seperti data berdirinya PT. BPR Aswaja Ponorogo, strategi pemasaran serta peningkatan jumlah nasabah pada tahun 2003 sampai 2012.

2. Wawancara

Wawancara digunakan sebagai teknik pengumpulan data apabila peneliti ingin melakukan studi pendahuluan untuk menemukan permasalahan yang harus diteliti, dan juga apabila peneliti ingin mengetahui hal-hal dari responden yang lebih mendalam dan jumlah respondennya sedikit atau lebih (Sugiyono, 2006: 194).

Dalam hubungan dengan penelitian ini, wawancara yaitu tanya jawab secara lisan dengan pihak-pihak yang dipandang mempunyai otoritas dengan obyek penelitian. Wawancara ini diperlukan untuk mendapatkan data yang tidak mungkin digambarkan dengan angka. Wawancara dilakukan dengan Direktur, Pengurus, serta beberapa karyawan.

Metode wawancara merupakan teknik pengumpulan data yang menggunakan pertanyaan secara lisan kepada subyek peneliti yaitu terhadap pimpinan. Dengan menggunakan metode wawancara ini untuk menggali informasi tentang strategi pemasaran dan peningkatan jumlah nasbah di PT. BPRAswaja.

3. Observasi (Pengamatan)

Metode pengumpulan data melalui pengamatan adalah proses dimana peneliti atau pengamat situasi penelitian, pengamat kondisi, tingkah laku dan interaksi (Gabriel Amin Silalahi, 2003: 64).

Teknik observasi digunakan untuk menggali data dari sumber data yang berupa peristiwa, tempat atau lokasi, dan benda, serta rekaman gambar. Observasi yang dilakukan dalam penelitian ini adalah pengamatan terhadap aktivitas bank, yaitu proses dan prosedur melakukan kegiatan perbankkan.

\section{Instrumen Penelitian}

Instrumen Pengumpulan Data merupakan alat bantu yang dipilih dan digunakan oleh peneliti dalam kegiatannya mengumpulkan agar kegiatan tersebut menjadi sistematis dan dipermudah olehnya. Instrumen penelitian "yang diartikan sebagai "alat bantu" merupakan saran yang dapat diwujudkan dalam benda, misalnya angket (questionnaire), daftar cocok (checklist) atau pedoman wawancara (interview guide atau interview schedule), lembar pengamatan atau panduan pengamatan (observation sheet atau observation schedule) soal tes, (investory), skala (scala), dan lain sebagainya (Suharsimi Arikunto, 2009:101).

Dalam hal ini peneliti menggunakan instrumen penelitian berupa pedoman wawancara yang berisi pertanyaanpertanyaan yang akan ditanyakan kepada narasumber yaitu pimpinan PT. BPR Aswaja Ponorogo.

\section{Teknik Analisis Data}

Analisis data menggunakan statistik. Menurut Gabriel Amin Silalahi (2003: 82) Statistik mempunyai banyak pengertian di antaranya adalah sebagai kumpulan metode yang dapat digunakan untuk menarik kesimpulan yang masuk akal dari suatu data.

Dalam penelitian ini menggunakan teknik analisis Regresi Linier Sederhana dan Uji t. Maka untuk mengetahui ada atau 
tidaknya pengaruh strategi pemasaran terhadap peningkatan jumlah nasabah pada PT. BPRAswaja dipergunakan :

\section{Analisis Regresi Linier Sederhana}

Dalam penelitian ini menurut Iqbal Hasan (2004: 63) "Regresi linier sederhana adalah regresi linier dimana variabel yang terlibat didalamnya hanya dua, yaitu satu variabel terikat $\mathrm{Y}$, dan satu variabel bebas $\mathrm{X}$ serta berpangkat satu.

\section{Uji T}

Uji t yaitu alat analisis untuk mengetahui apakah variabel bebas secara individual mempunyai pengaruh yang signifikan terhadap variabel terikat. (Gabriel Amin Silalahi, 2003: 86)

\section{HASIL PENELITIAN}

\section{Variabel Strategi Pemasaran dan Variabel Jumlah Nasabah}

Variabel strategi pemasaran dapat dideskripsikan bahwa dengan jumlah data (N) sebanyak 10 mempunyai deskripsi data sebagai berikut : (a) jumlah skor total sebesar 201563; (b) nilai rata-rata hitung (mean) sebesar 2.02E4; (c) median sebesar 2.02E4; (d) modus sebesar; $18275^{\text {a }}$ (e) stansar deviasi sebesar 1.552E3; (f) nilai minimum sebesar 18275; (g) nilai maximum sebesar 22833.

Variabel jumlah nasabah dapat dideskripsikan dengan jumlah data $(\mathrm{N})$ sebanyak 10 mempunyai deskriptif data sebagai berikut : (a) jumlah skor total sebesar 3.76E4 ; (b) nilai rata-rata hitung (mean) sebesar 3.7590E3; (c) median sebesar 3.7250E3; (d) modus sebesar 3.12E3 ${ }^{\text {a }}$; (e) standar deviasi sebesar 3.70135E2; (f) nilai minimum sebsesar 3115.00; (g) nilai maximum sebesar 4407.00.

\section{Hasil Analisis Regresi Linier Sederhana}

Atas dasar perhitungan dapat dibuat garis regresi sebagai berikut $Y=9,622+$
0,186X, artinya konstanta sebesar 9,622 artinya jika strategi $(\mathrm{X})$ nilainya adalah 0 , maka jumlah nasabah (Y) nilainya sebesar 9,622.

Konstanta regresi variabel strategi pemasaran (X) sebesar 0,186 artinya jika strategi pemasaran mengalami kenaikan $1 \%$, maka jumlah nasabah (Y) juga akan mengalami peningkatan sebesar $0,186 \%$. Koefisien bernilai positif artinya terjadi hubungan positif antara strategi pemasaran dengan peningkatan jumlah nasabah, semakin tinggi strategi pemasaran semikin meningkat jumlah nasabah pada PT. BPR Aswaja.

\section{Hasil Uji t}

Berdasarkan hasil perhitungan diketahui bahwa untuk variabel strategi pemasaran uji $\mathrm{t}$ diperoleh $=3,524$ dan $\mathrm{t}_{\text {tabel }}$ dicari dengan signifikansi 0,05 dengan uji dua pihak dan data dalam penelitian ini $(n)=10$, maka diperoleh $t_{\text {tabel }}$ sebesar 1,859. Ho ditolak, Ha diterima jika $t_{\text {hitung }}>t_{\text {tabel }}$, nilai $t_{\text {hitung }}>t_{\text {tabel }}$ yaitu 3,524 > 1,859. Maka, Ho ditolak, Ha diterima yang artinya bahwa ada pengaruh secara signifikan antara strategi pemasaran dengan peningkatan jumlah nasabah PT. BPR Aswaja Ponorogo.

\section{Simpulan Hasil Pengujian Hipotesis}

Atas dasar hasil pengujian hipotesis dapat diambil simpulan sebagai berikut :

Dari hasil perhitungan atau pengujian yang dilakukan diperoleh persamaan regresi sebagai berikut $\mathrm{Y}=9,622+0,186 \mathrm{X}$, simpulannya adalah apabila strategi pemasaran ditingkatkan satu kali akan terjadi kenaikan nasabah sebanyak 0,186 apabila faktor yang lainnya tetap.

Berdasarkan Uji t nilai thitung adalah $\mathrm{t}_{\text {hitung }}$ adalah 3,524 dan $\mathrm{t}_{\text {tabel }} 1,859$, hal ini berarti bahwa nilai $t_{\text {hitung }} \geq t_{\text {tabel }}(3,524>1,859)$. Atas dasar uji beda pengaruh tersebut dapat disimpulkan Ho ditolak, artinya ada beda pengaruh antara Strategi Pemasaran terhadap 
Peningkatan Jumlah Nasabah pada PT. BPR Aswaja Ponorogo.

\section{PEMBAHASAN}

\section{Strategi pemasaran}

Berdasarkan data yang diperoleh strategi pemasaran yang digunakan pada PT. BPR Asawa Ponorogo dilakukan dengan dua cara yaitu Brosur dan Door to Door. Dimana perbandingan strategi pemasaran pada tahun 2003-2004 sebesar 6,55\%, tahun 2004-2005 sebesar 3,02\%, tahun 2005-2006 sebesar 2,42\%, tahun 2006-2007 sebesar 8,72\%, tahun 20072008 sebesar 9,89\%, tahun 2008-2009 sebesar 12,92\%, tahun 2009-2010 sebesar 11,04\%, pada tahun 2010-2011 sebesar $7,53 \%$, pada tahun 2011-2012 sebesar 2,68\%. Jadi dapat diketahui bahwa biaya pemasaran yang digunakan PT. BPR Aswaja Ponorogo tiap tahunnya tidak sama dan cenderung turun.

2. Peningkatan jumlah nasabah

Dari data yang diperoleh pada PT. BPR Aswaja Ponorogo dapat diketahui bahwa selama tahun 2003-2004 mengalami peningkatan $2,40 \%$, tahun 2004-2005 mengalami peningkatan sebesar 3,29\%, tahun 2005-2006 mengalami peningkatan sebesar 5,49\%, tahun 2006-2007 mengalami peningkatan sebesar 7,13\%, tahun 2007-2008 mengalami penurunan sebesar 4,21\%, 2008-2009 mengalami suatu peningkatan yaitu sebesar $14,76 \%$, pada tahun 2009 2010 mengalami penurunan sebesar $5,65 \%$, pada tahun 2010-2011 mengalami penurunan sebesar $8,22 \%$, pada tahun 2011-2012 mengalami peningkatan sebesar $2,10 \%$.

3. Pengaruh strategi pemasaran terhadap peningkatan jumlah nasabah

Hasil penelitian menunjukkan bahwa biaya pemasaran berpengaruh terhadap jumlah nasabah yang diperoleh. Hal ini menunjukkan bahwa peningkatan biaya pemasaran diperlukan oleh BPR untuk meningkatkan jumlah nasabah.

Dapat dilihat hasil persamaan garis regresi $\mathrm{Y}=9,622+0,186 \mathrm{X}$, sedangkan untuk uji $\mathrm{t}$ diperoleh nilai thitung adalah 3,524 dan ttabel sebesar 1,859. Hal ini berarti bahwa nilai $t_{\text {hitung }}>t_{\text {tabel }}$ yaitu $3,524>1,859$ yang artinya bahwa Ho ditolak, Ha diterima artinya ada beda pengaruh strategi pemasaran terhadap peningkatan jumlah nasabah pada PT. BPR Aswaja Ponorogo.

Dari hasil penelitian menunjukkan bahwa biaya pemasaran mempunyai hubungan sekaligus pengaruh terhadap peningkatan jumlah nasabah di PT. BPR Aswaja. Apabila BPR meningkatkan biaya pemasaran, dapat pula terjadi peningkatan jumlah nasabah yang diperoleh. Dengan adanya biaya pemasaran pihak BPR akan memperoleh hasil yang diinginkan.

\section{PENUTUP}

\section{Simpulan}

1. Dalam variabel strategi pemasaran yang dilakukan oleh PT. BPR Aswaja Ponorogo dilakukan dengan cara penyebaran Brodur dan Door to door. Dapat diketahui bahwa pada tahun 2003 ke tahun 2004 mengalami kenaikan sebesar $6,55 \%$. Pada tahun 2004 ketahun 2005 mengalami kenaikan sebesar 3,02\%. Pada tahun 2005 ketahun 2006 mengalami kenaikan sebesar 2,42\%. Pada tahun 2006 ke tahun 2007 mengalami kenaikan sebesar $8,72 \%$. Pada tahun 2007 ke tahun 2008 mengalami kenaikan sebesar 9,89\% pada tahun 2008 ke tahun 2009 mengalami kenaikan sebesar 12,92\%. Pada tahun 2009 ke tahun 2010 diketahui mengalami penurunan sebesar 11,04\%. Pada tahun 2010 ke tahun 2011 diketahui mengalami penurunan sebesar $7,53 \%$. Pada tahun 2011 ke tahun 2012 diketahaui mengalami penurunan sebesar $2,68 \%$. Sehingga dapat 
diketahui biaya pemasaran yang dilakukan PT. BPR Aswaja Ponorogo tiap tahunnya tidak sama dan cenderung turun.

2. Dalam variabel peningkatan jumlah nasabah pada PT. BPR Aswaja Ponorogo dapat diketahui bahwa pada tahun $2003 \mathrm{ke}$ tahun 2004 jumlah nasabah mengalami kenaikan sebesar 2,40\%. Pada tahun 2004 ke tahun 2005 jumlah nasabah mengalami kenaikan sebesar 3,29\%. Pada tahun 2005 ke tahun 2006 jumlah nasabah mengalami kenaikan sebesar 5,49\%. Pada tahun 2006 ke tahun 2007 jumlah nasabah mengalami kenaikan 7,13\%. Pada tahun 2007 ke tahun 2008 jumlah nasabah mengalami penurunan sebesar 4,21\%. Pada tahun 2008 ketahun 2009 jumlah nasabah mengalami kenaikan sebesar 14,76\%. Pada tahun 2009 ke tahun 2010 mengalami penurunan sebesar 5,65\%. Pada tahun 2010 ke tahun 2011 mengalami penurunan sebesar $8,22 \%$. Pada tahun 2011 ke tahun 2012 jumlah nasabah mengalami peningkatan sebesar $2,10 \%$.

3. Pengaruh strategi pemasaran terhadap peningkatan jumlah nasabah berdasarkan hasil analisis regresi linier sederhana diketahui bahwa strategi pemasaran berpengaruh signifikan terhadap jumlah nasabah. Jadi ada pengaruh strategi pemasaran terhadap jumlah nasabah pada PT. BPR Aswaja Ponorogo tahun 2003-2012 dapat dibuktikan dengan $\mathrm{t}_{\text {hitung }}>\mathrm{t}_{\text {tabel }}$. Dalam hasil analisis diketahui bahwa untuk variabel strategi pemasaran uji $t$ diperoleh $\mathrm{t}$ hitung $=3,524$ dan $\mathrm{t}$ tabel dicari pada signifikan 0,05 dengan uji dua pihak dan jumlah data dalam penelitian ini adalah $(\mathrm{n})=10$, maka diperoleh $t$ tabel 1,859. Ho ditolak, Ha diterima jika $\mathrm{t}_{\text {hitung }}>\mathrm{t}_{\text {tabel }}$, nilai $\mathrm{t}_{\text {hitung }}>\mathrm{t}_{\text {tabel }}$ yaitu 3,524 >1,859. Maka Ho ditolak, Ha diterima yang artinya bahwa ada pengaruh secara signifikan antara strategi pema- saran dengan jumlah nasabah pada PT. BPRAswaja Ponorogo.

\section{Saran}

\section{Bagi BPR}

Perusahaan perlu memperhatikan dan menerapkan strategi pemasaran yang lain dan menggunakan cara-cara pemasaran yang lebih efektif seperti melakukan pemasaran melalui media elektronik atau undian berhadiah.

\section{Bagi Karyawan}

Karyawan diharapkan mampu meningkatkan strategi pemasaran yang tepat sehingga posisi atau kedudukan perusahaan di pasar dapat dipertahankan dan sekaligus dan ditingkatkan.

\section{DAFTAR PUSTAKA}

Basu Swasta dan Irawan. 2008. Manajemen Pemasaran Modern. Yogyakarta: Liberty Offset.

Buchari Alma. 2011. Manajemen Pemasaran dan Pemasaran Jasa. Bandung: Alfabeta.

Gabriel Amin Silalahi. 2003. Metodologi Penelitian dan Studi Kasus. Sidoarjo: Citra Media.

Hartono. 2008. Statistik Untuk Penelitian. Yogyakarta: PUSTAKABELAJAR.

Husaini Usman dan Purnomo Setiady Akbar. 2006. Pengantar Statistik. Jakarta: PT. Bumi Aksara.

Iqbal Hasan. 2004. Analisis Data Penelitian dengan Statistik. Jakarta: PT. Bumi Aksara.

Kasmir. 2007. Dasar-dasar Perbankan. Jakarta: PT. Raja Grafindo Persada.

Kasmir. 2010. Pemasaran Bank. Jakarta: Kencana Prenada Media Group. 
Rambat Lupiyoadi. 2001. Manajemen Pemasaran Jasa. Jakarta: PT. Salemba Emban Patria.

Sofjan Assauri. 2010. Manajemen Pemasaran. Jakarta: PT. Raja Grafindo Persada.

Sugiyono. 2006. Metode Penelitian Kuantitatif, Kualitatif dan $R \& D$. Bandung: Alfabeta.

Sugiyono. 2007. Metode Penelitian Kuantitatif, Kualitatif dan $R \& D$. Bandung: Alfabeta.

Suharsimi Arikunto. 2002. Prosedur Penelitian Suatu Pendekatan Praktik. Jakarta: Rineka Cipta.
Suharsimi Arikunto. 2009. Manajemen Penelitian. Jakarta: PT. Rineka Cipta.

Sumadi Suryabrata. 2011. Metodologi Penelitian. Jakarta: Raja Grafindo Persada.

Thamrin Abdullah dan Francis Tantri. 2012. Manajemen Pemasaran. Jakarta: PT. Raja Grafindo Persada.

http://id.pdfsb.com/readonline (Diunduh pada 26 Februari 2013)

(Diunduh 20 April 2013)

http://mirave21.wordpress.com./tag/pengerti an-nasabah/(diunduh 20 April 2013) 